\title{
Moral Messages in Dutch Realist Art of the Seventeenth- Century Golden Age
}

\author{
David T. Roth
}

The Australian National University

\begin{abstract}
The 'iconographic' faction of modern scholars of Dutch realist art in its Golden Age of the seventeenth century have claimed that a principal function of these works was to transmit educational, moral and uplifting messages. Here I argue that the evidence indicates otherwise. Buying decisions were made on economic, social, egotistical or aesthetic grounds. Moreover, there was a strong demand for works of a far less moral nature that tended to be displayed in spaces open to visitors. The continued survival of such frankly suggestive works indicates that Golden Age art was not necessarily a springtime of moral improvement.
\end{abstract}

The transmission of moral messages in Golden Age Dutch art is a core claim of the 'iconographic' faction of scholars of Dutch realist art. Jeroen Dekker writes:

17th century Dutch genre painting played a major role in the promotion of the pursuit of family and educational virtues. Packing moralistic messages in fine paintings was considered as a very effective moralistic communication policy in a culture in which sending such moralising messages was very popular. ${ }^{1}$

Dekker's views imply a coordinated strategy of moral education by Dutch artists. ${ }^{2}$ This claim is inconsistent with the available evidence, which indicates that artists of the period were largely motivated by straightforward commercial considerations and not by moral or educational aspirations. They did not conduct explicit morals campaigns or have an organised strategy to 'civilise' their customers. Although patrons and buyers did

1 Jeroen J. H. Dekker, 'Beauty and Simplicity: The Power of Fine Art in Moral Teaching on Education in Seventeenth-Century Holland', Journal of Family History 34, no. 166 (2009): 166, doi.org/10.1177/0363199008328377.

2 Dekker, 'Beauty and Simplicity', 169. 
undoubtedly wish to enhance their image via 'moral' works, I show that moral and educational improvement was not a significant factor in the buying, selling or commissioning of paintings. Buying decisions were made on economic, social, egotistical or aesthetic grounds, and artists met that demand. Moreover, there was a demand for works of a far less moral nature, which were displayed in the spaces of private homes more open to visitors and public, such as entry halls. ${ }^{3}$ As I demonstrate, the open display and continuing abundant survival of these 'low' works to the present day shows that they were valued and continued to be valued, which weakens Dekker's notion that Golden Age art was a springtime of moral improvement.

The 'iconographic' school of art criticism began in the 1970s. Before then, the consensus had been that Dutch realist art was a 'mirror of everyday life. ${ }^{4}$ Consistent with this interpretation is the impression that we are looking at 'real' people, houses and landscapes, not 'captains or kings' or Valhallas, but technically superb scenes from the life of the people. ${ }^{5}$ In 1983 Svetlana Alpers advanced a more nuanced 'descriptivist' approach, which, according to its critics, most notably Eddy De Jongh, 'plays down' any meaning that cannot be found on the surface. ${ }^{6}$ These realist interpretations began to be contested in the 1970s by 'iconologists', most notably De Jongh. They argued that the images have a deeper meaning, for instance, to give a moral message or to educate the viewer. ${ }^{7}$

3 Lotte Van de Pol, 'The Whore, the Bawd, and the Artist: The Reality and Imagery of SeventeenthCentury Dutch Prostitution', Journal of Historians of Netherlandish Art 2, no. 1-2 (2010): 1, doi. org/10.5092/jhna.2010.2.1.3.

4 Mariët Westermann, 'After Iconography and Iconoclasm: Current Research in Netherlandish Art, 1566-1700', Art Bulletin 84, no. 2 (June 2002): 352, 357. See also Kim Sluijter, Locating 'Realism' in Seventeen-Century Dutch Art_Looking at the Art of Everyday Life (Saarbrūcken, Germany: Lap Lambert Academic Publishing, 2011), 5, doi.org/10.2307/3177273.

5 For masterly technique, see Roger West and Hank G. Van Veen, 'Gaze as Depicted in Vermeer's Girl With a Pearl Earring', Journal of General Psychology 134, no. 3 (2007): 313. See also Westermann, 'After Iconography and Iconoclasm', 358; Walter A. Liedtke, A View of Delft: Vermeer and His Contemporaries (Zwolle: Waanders Publishers, 2000), 146.

6 Svetlana Alpers, The Art of Describing: Dutch Art in the Seventeenth Century (Chicago: University of Chicago Press, 1984). For criticism of Alpers's views, see Eddy De Jongh's review of The Art of Describing in Netherlands Quarterly for the History of Art 14, no. 1 (1984): 51, 56-57, doi. org/10.2307/3780534. See page 56 for comment on Alpers's 'surface' view.

7 For example, see Dekker, 'Beauty and Simplicity', 166-87. See also Madlyn Millner Kahr, 'Vermeer's “Girl Asleep”: A Moral Emblem', Metropolitan Museum Journal 6 (1972): 115-32, doi. org/10.2307/1512637. 
In this 'iconographic' or 'emblematic' framework, moral and other types of messages can be found in objects and their arrangement, facial expressions or even postures, such as in Johannes Vermeer's Girl Asleep. For Madlyn Kahr, the sleeping woman at the table, who rests her head on her hand, epitomises the vice of sloth, the 'root of all sin'. The near empty wineglass on the table suggests that the woman is also drunk. Kahr shows that the 'head on hand' theme, representing laziness or even erotic dreams, as in Albrecht Dürer's The Dream of the Doctor (c. 1498), had a long history. ${ }^{8}$

De Jongh strongly criticised Alpers's The Art of Describing, rating it as a 'failed book' because he thought that her downplaying of deeper meanings was unhistorical. ${ }^{9}$ In his view, description and iconological perception were not mutually exclusive. According to Mariët Westermann, De Jongh is convinced of the 'repetitive moralising' of Golden Age art, and he claims that clients tolerated and expected it. ${ }^{10}$ Westermann writes that other art historians question whether consumers really expected or desired 'moral sustenance'. Moreover, she says that moral messages were not necessarily 'the product of an active moralising on the part of the artist'. ${ }^{11}$ Her more recent 2002 article on current research in Dutch art discusses these debates in more detail. ${ }^{12}$

Before analysing the respective roles of morality and economics, it is necessary to understand the art market of the period. A huge boom occurred between 1600 and 1660. From 1600 there was a 16-fold increase in working artists in response to the astonishing increase in demand. ${ }^{13}$ But paintings were not the exclusive luxury of the elite. The extraordinary number of paintings in even quite modest Dutch households was remarked on by foreign visitors, ${ }^{14}$ with some paintings costing as little as the daily

8 Kahr, 'Vermeer's “Girl Asleep”, 119.

9 De Jongh, [review of Alpers The Art], 51, 56-57. See also the Appendix in Alpers's book for her critique of the 'icon' position.

10 Mariët Westermann, review of Eddy De Jongh Kwesties van Betekenis: Thema en Motief in de Nederlandse Schilderkunst van de Zeventiende Eeuw (Leiden: Primavera 1995) in Burlington Magazine 138, no. 1116 (March 1996): 198-200.

11 Westermann, [review of De Jongh Kwesties], 199.

12 Westermann, 'After Iconography and Iconoclasm'. See also Sluijter, Locating 'Realism', 8-9.

13 Maarten Prak, 'Guilds and the Development of the Art Market during the Dutch Golden Age', Simiolus: Netherlands Quarterly for the History of Art 30, no. $3 / 4$ (2003): 238, doi.org/10.2307/ 3780918.

14 Simon Schama, The Embarrassment of Riches: An Interpretation of Dutch Culture in the Golden Age (New York: Vintage Books, 1997), 318. 
wage of a skilled workman. ${ }^{15}$ Cheaper art prints were also available for poorer folk. An estimated 2-5 million paintings were produced in the seventeenth century. ${ }^{16}$ This explosion in artistic activity reflected the exceptional economic growth of the Republic. It was also evidence that some of this wealth was distributed to more humble citizens-enough to buy non-essentials such as artworks. ${ }^{17}$ The growth in demand in a time of rapid social change reflects the function of artworks as 'positional goods', whereby they signal the owner's social standing. ${ }^{18}$ The eminent French sociologist Pierre Bourdieu thought that the consumption of art was an act of social positioning. ${ }^{19}$ Modestly priced, mass-produced artworks would have helped to elevate the status of lower middle-class homes over that of their working-class neighbours, while at the upper end of the market, some 'top end' paintings sold for multiples of the annual earnings of a skilled worker. ${ }^{20}$ Some painters, for example Vermeer, were not in the open market, but relied on a few rich patrons. ${ }^{21}$

Paintings were not the only artworks functioning as positional goods during the Golden Age. Exquisitely handcrafted and costly doll's houses were considered to be status symbols. ${ }^{22}$ Artworks also served as positional signals for the civic pride of towns - their possession signified and reinforced status and political clout. ${ }^{23}$ Official or semiofficial bodies

15 Schama, The Embarrassment of Riches, 167. The daily wage of a journeyman was around 27 stuivers (1.4 guilders). Some paintings sold for as little as a guilder (see page 319). But Muizelaar and Phillips claim that an ordinary workman's daily wage was around 1 guilder. See Klaske Muizelaar and Derek Phillips, Picturing Men and Women in the Dutch Golden Age: Paintings and People in Historical Perspective (New Haven: Yale University Press, 2003), 22.

16 Prak, 'Guilds', 238. See also J. L. Price, Dutch Culture in the Golden Age (London: Reaktion Books 2011), Kindle ed., loc 1542.

17 See Chapter 5 of Schama, The Embarrassment of Riches.

18 For definition of positional goods, see Investopedia, www.investopedia.com/terms/p/positionalgoods.asp\#axzz26ypvvbPo, accessed 26 September 2012. See also Muizelaar and Phillips, Picturing Men and Women, 69: 'the presence of an artist's work ... helped to establish or maintain his (or more rarely, her) reputation'.

19 Michael Grenfell and Cheryl Hardy, Art Rules: Pierre Bourdieu and the Visual Arts (Oxford; New York: Berg, 2007), Kindle ed., loc 1111. See also Pierre Bourdieu, Distinction: A Social Critique of the Judgement of Taste (Cambridge, MA: Harvard University Press, 1984).

20 For prices, see Prak, 'Guilds', 239.

21 John Michael Montias, 'Vermeer's Clients and Patrons', Art Bulletin 69, no. 1 (1987): 69, doi.org/ $10.2307 / 3051083$.

22 Susan Broomhall, 'Imagined Domesticities in Early Modern Dutch Dollhouses', Parergon 24, no. 2 (2007): 55-56: 'Oortman spent ... 20,000 to 30,000 guilders', 'Rothé spent ... 1700 guilders'. 23 Eric Jan Sluijter, 'On Brabant Rubbish, Economic Competition, Artistic Rivalry, and the Growth of the Market for Paintings in the First Decades of the Seventeenth Century', Journal of Historians of Netherlandish Art 1, no. 2 (2011): 2, doi.org/10.5092/jhna.2009.1.2.4: 'The idea that the art of painting contributed to their renown.' 
commissioned 'ego' works such as Rembrandt's colossal Night Watch. ${ }^{24}$ Religious patrons also sought secular and personal prestige in fine artwork. ${ }^{25}$ For some, piety was a secondary consideration.

Simon Schama has argued in The Embarrassment of Riches that there was a major tension between the conspicuous consumption of luxury goods and the Calvinist dominant morality, which emphasised thrift and frugality. ${ }^{26}$ Dekker argues that Schama's 'embarrassment' was overcome for most people by the acquisition of morally elevating and educational artworks on 'the family, parenting, childhood and education'. ${ }^{27}$ He claims that such works dominated the 'moralistic' genre. There was a dominant taste, he says, for moral messages and artists catered to that taste. ${ }^{28}$ But Dekker's repeated assertions that Dutch artists had a 'communication policy', 'strategies of moral education' or engaged in a 'propaganda offensive' are difficult to accept, because all these terms connote collaboration, organisation and planning. ${ }^{29}$

There seems to be no explicit evidence that moral elevation was a concerted aim of artists in the genre, nor is there evidence of coordination or encouragement of their 'civilising' efforts by moral guardians in church or state. It was simply a case of supply and demand. For the wealthier buyers, 'the painter was a supplier of goods like any other'. ${ }^{30}$ Several economic history studies of the Dutch art market show that moral or educational aims were not factors that artists, assessors or dealers expressly considered when valuing artworks. ${ }^{31}$

Artists' guilds did give some 'not too strict' weighting to moral factors. ${ }^{32}$ But, if moral considerations were important factors in a painting's value, surely the valuers and buyers would have stressed them. Bernard

24 Rembrandt's Night Watch is about 4.5 metres x 3.5 metres.

25 Prak, 'Guilds', 237.

26 Schama, The Embarrassment of Riches, 188: 'Prosperity would remain intact only so long as the divine precepts were obeyed.'

27 Dekker, 'Beauty and Simplicity',167, 182.

28 Dekker 'Beauty and Simplicity', 169-70.

29 Dekker 'Beauty and Simplicity', 169, 182.

30 Paul Zumthor, Daily Life in Rembrandt's Holland (Stanford: Stanford University Press 1994), 195.

31 Neil De Marchi and Hans J. Van Miegroet, 'Art, Value and Market Practices in the Netherlands in the Seventeenth Century', Art Bulletin 76, no. 3 (1994): 451-64. See also Sluijter, 'On Brabant Rubbis', 1-17. See also 'Introduction' by Eric Jan Sluijter in Anna Tummers and Koenraad Jonckheere, Art Market and Connoisseurship: A Closer Look at Paintings by Rembrandt, Rubens and their Contemporaries (Amsterdam: Amsterdam University Press, 2008).

32 W. Martin, 'The Life of a Dutch Artist. Part VI-How the Painter Sold His Work', Burlington Magazine for Connoisseurs 11, no. 54 (September 1907): 357. 
Mandeville (1670-1733), an economic commentator active just after the Golden Age, thought that market value was based on usefulness, scarcity and the artist's name, but made no mention of morality. ${ }^{33}$ The didactic aims in 'moral' genre paintings pointed to by twentieth- and twenty-firstcentury art historians are not remarked on in seventeenth-century art treatises, nor is there evidence about the meanings they had for viewers. ${ }^{34}$ The demand for 'virtuous' artworks was influenced by their function as positional goods, because they gave the owners and their households a certain social standing and prestige in the eyes of their social group, neighbours, employees and social inferiors. This status was not necessarily consistent with the actual practices and moral values of the owners, but enhanced business and political prospects. But there was also a clear demand for less elevating works, as evidenced by their survival to the present day.

One difficulty in assessing the relative demand of 'high' and 'low' art is the fact that the paintings surviving today are not a representative sample. The extant Golden Age paintings represent perhaps less than 1 per cent of the total number produced. ${ }^{35}$ The paintings we see in galleries, museums or in private hands have survived by what may be termed a Darwinian struggle, with some positive correlation between longevity and considerations of technical quality, perceived value and the artist's 'name', subject to the whims of fashion and taste. ${ }^{36}$ Chance survivals in storerooms and attics also played a part. It is reasonable to assume that the happy few survivors are heavily concentrated at the top end of the market. ${ }^{37}$ Works considered to be cheap or unfashionable would risk being unceremoniously discarded on the owner's demise, change of address or business failure. If 'moral paintings' did survive more than 'low' paintings, that would tend to confirm Dekker's thesis. But, in this 'survival of the fittest', the preservation of 'low' art indicates that moral quality was not a predominating selection criterion.

33 De Marchi and Van Miegroet, 'Art, Value and Market Practices', 454-55.

34 Muizelaar and Phillips, Picturing Men and Women, 123.

35 Muizelaar and Phillips, Picturing Men and Women, 1.

36 De Marchi and Miegroet, 'Art, Value and Market Practices', 457: 'Therefore "faults and beauties" will be differently evaluated as the composition of tastes in a population shifts over time.' Also see Muizelaar and Phillips, Picturing Men and Women, 1.

37 Price, Dutch Culture in the Golden Age, loc 1631: 'Much that was cheap and shoddy has been lost.' 


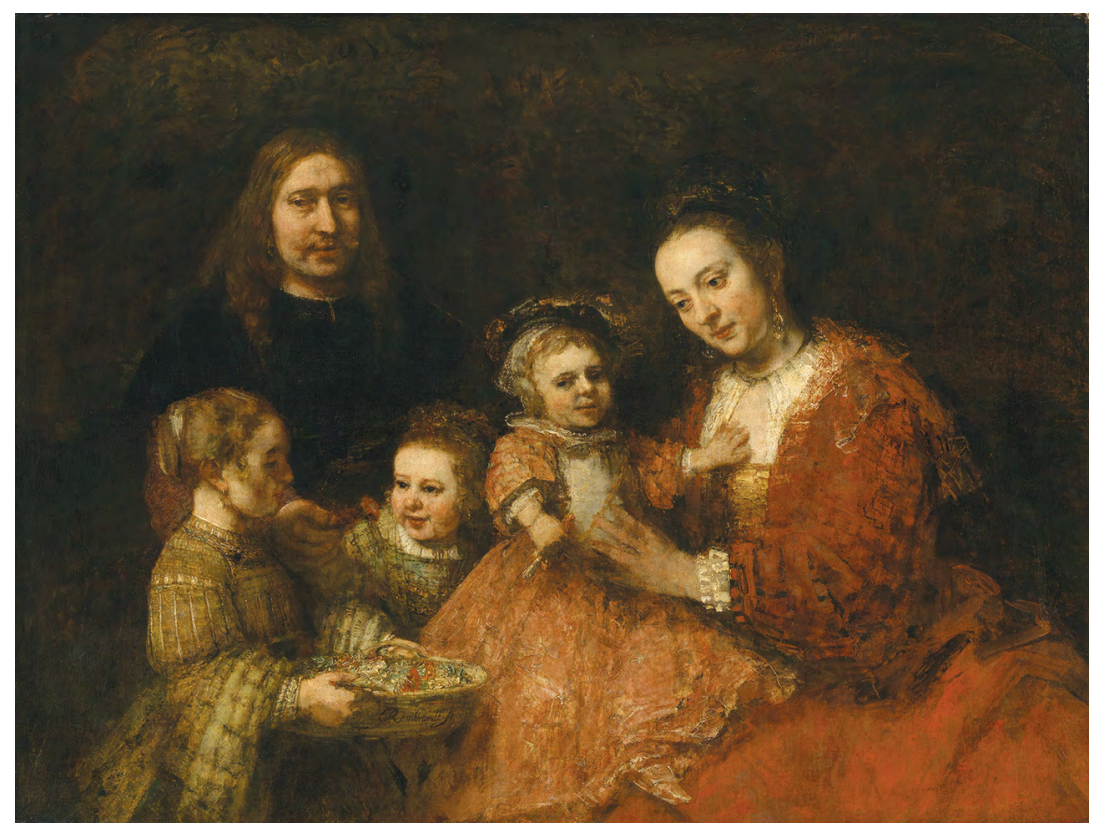

Figure 1: Rembrandt van Rijn, Familienbild [Portrait of a Family], c. 1668.

Herzog Anton Ulrich Museum, Braunschweig, Germany. Wikimedia Commons.

To consider Dekker's claims fairly, we need to look at his discussion of 'moral' examples. He says that an ideal picture of loving parenthood is represented in Rembrandt's Portrait of a Family (Figure 1). The fruit and flowers in the basket refer to 'a fertile marriage and good upbringing. ${ }^{38}$ He refers to many other examples of family portraits by Gabriël Metsu, Jan Mitjens and their contemporaries. The emphasis on family life was also reinforced by messages on good and bad motherhood, for example, in Woman Combing a Child's Hair, by Quirijn van Brekelenkam, or in Pieter de Hooch's The Pantry where there is an atmosphere of love and affection. ${ }^{39}$ Jan Steen's The Meagre Kitchen, as a counter-example and warning, shows the disorder and child neglect resulting from poverty and domestic disharmony. ${ }^{40}$ His cosy, well-fed and harmonious Fat Kitchen was the desired goal.

40 Dekker, 'Beauty and Simplicity', 176. 
Dekker says that messages about chastity were frequent, such as in Jacob Gerritz's Four-Year-Old Girl with Cat and Fish. Sexual lust is represented by the cat trying to eat the fish. The young girl prevents this, showing the triumph of virtue and restraint over base instinct and immediate gratification. ${ }^{41}$ The child is confident, well cared for and beautifully dressed, a paradigmatic case of parental affection and conspicuous consumption. One possible, but less plausible, explanation of the cat's distress may be that it is expecting the small fish for dinner and the child is naughtily teasing it. But perhaps, in this case, I would agree with Dekker that a moral message was intended.

The idea that family portraits or portraits of children were bought primarily because of their moral or educational message for the owner and household is a weak point in Dekker's argument. It is true that there was a plausible fertility message in the child pictures. ${ }^{42}$ And it is probable that motivation to buy pictures in general was the desire to show a message about the household, as argued above. But I do not think that the 'family' portraits were primarily positional goods because, based on John Loughman and John Michael Montias's study of art inventories, they tended to be hung in more private spaces of the home. ${ }^{43}$ These rooms were loosely designated in inventories as keuken (kitchen), binnenhaard (inner hearth), achtercamer (back room) or zijkamertje (side room/bedroom). ${ }^{44}$

Dekker claims further that 'family' or 'child' pictures educated parents on how to raise children. ${ }^{45}$ Yet, this alleged role must have been very limited. The range of what can be communicated via artworks is severely restricted when compared to other sources of potential instruction: books,

41 Dekker, 'Beauty and Simplicity', 181-82.

42 Muizelaar and Phillips, Picturing Men and Women, 143: 'some images were believed to help ensure the birth of beautiful children'.

43 Muizelaar and Phillips, Picturing Men and Women, 73: 'portraits of a personal nature were hung in private rooms, away from public gaze'. This cites John Loughman and John Michael Montias, Public and Private Spaces: Works of Art in Seventeenth-century Dutch Houses (Zwolle: Waanders, 2000). For example, see 67-68. See also 'Montias Database of 17th Century Dutch Art Inventories', The Frick Collection, research.frick.org/montias, accessed 26 September 2012. This inventory of deceased estates, bankruptcies and auctions is referenced in Chapter 2 of Loughman and Montias. 44 Loughman and Montias, Public and Private Spaces, 43, 67, and 'Montias Database' discussion in Chapter 2.

45 Dekker, 'Beauty and Simplicity', 169. For further discussion of this role, see also Jeroen Dekker and Leendert F. Groenendijk, 'The Republic of God or the Republic of Children? Childhood and Child-Rearing after the Reformation: An Appraisal of Simon Schama's Thesis about the Uniqueness of the Dutch Case', Oxford Review of Education 17, no. 3 (1991): 322, doi.org/ $10.1080 / 0305498910170306$. 
pamphlets, relatives, other parents and so on. Artworks can exemplify but the instructional potential of a given painting is limited and static. Moreover, the child-raising functions of paintings becomes somewhat ambiguous, given the 'arsenal of horrors' and 'repertoire of naughtiness' represented in many 'child' paintings of the time. ${ }^{46}$ It is more plausible that the reason for buying paintings of children, at least of well-behaved offspring, was no different from that of proud parents ordering studio photographs of their progeny today. Dutch parents were notoriously fond of their families, to a degree 'arrestingly unlike those of other European cultures'. ${ }^{47}$ Having looked at Dekker's 'family-orientated' art world, we now need to examine its underside.

The representation of brothels and prostitution in Golden Age art has been studied by Lotte van de Pol. She writes that bordeeltje- 'brothel painting' - was a popular subgenre. ${ }^{48}$ Steen, favourably mentioned in Dekker's examples of moral art, painted over 40 bordeeltje and many more 'dubious' paintings, such as The Wench, in which coins are clearly visible in the woman's hand. Dekker claims that Vermeer, whose 'strategy was focused on beautifying moral messages', allegedly used fine art to educate in the virtues. ${ }^{49}$ But what then are we to make of his much-discussed work The Procuress (Figure 2) $?^{50}$ I cannot agree with Edward Snow's odd assertion that the procuress and her client are a 'loving couple'. ${ }^{51}$ The commercial nature of the relationship is plain to see.

46 Schama, The Embarrassment of Riches, 483-84.

47 Schama, The Embarrassment of Riches, 485-86.

48 Van de Pol, 'The Whore, the Bawd, and the Artist', 1. See also Harriet Amy Stone, Tables of Knowledge: Descartes in Vermeer's Studio (Ithaca, NY: Cornell University Press, 2006), 23.

49 Dekker, 'Beauty and Simplicity', 180.

50 See discussion of this painting and its obscene symbolism in Liedtke, A View of Delft, 198-201. Note that there were less refined 'Procuress' works by other artists- for example, by Van Baburen and Christiaen van Couwenberg. See also Edward Snow, 'Vermeer's Procuress', Threepenny Review, no. 55 (Autumn 1993): 30-31. Note that the painting was given its present name only at the end of the nineteenth century.

51 Snow, 'Vermeer's Procuress', 31. 


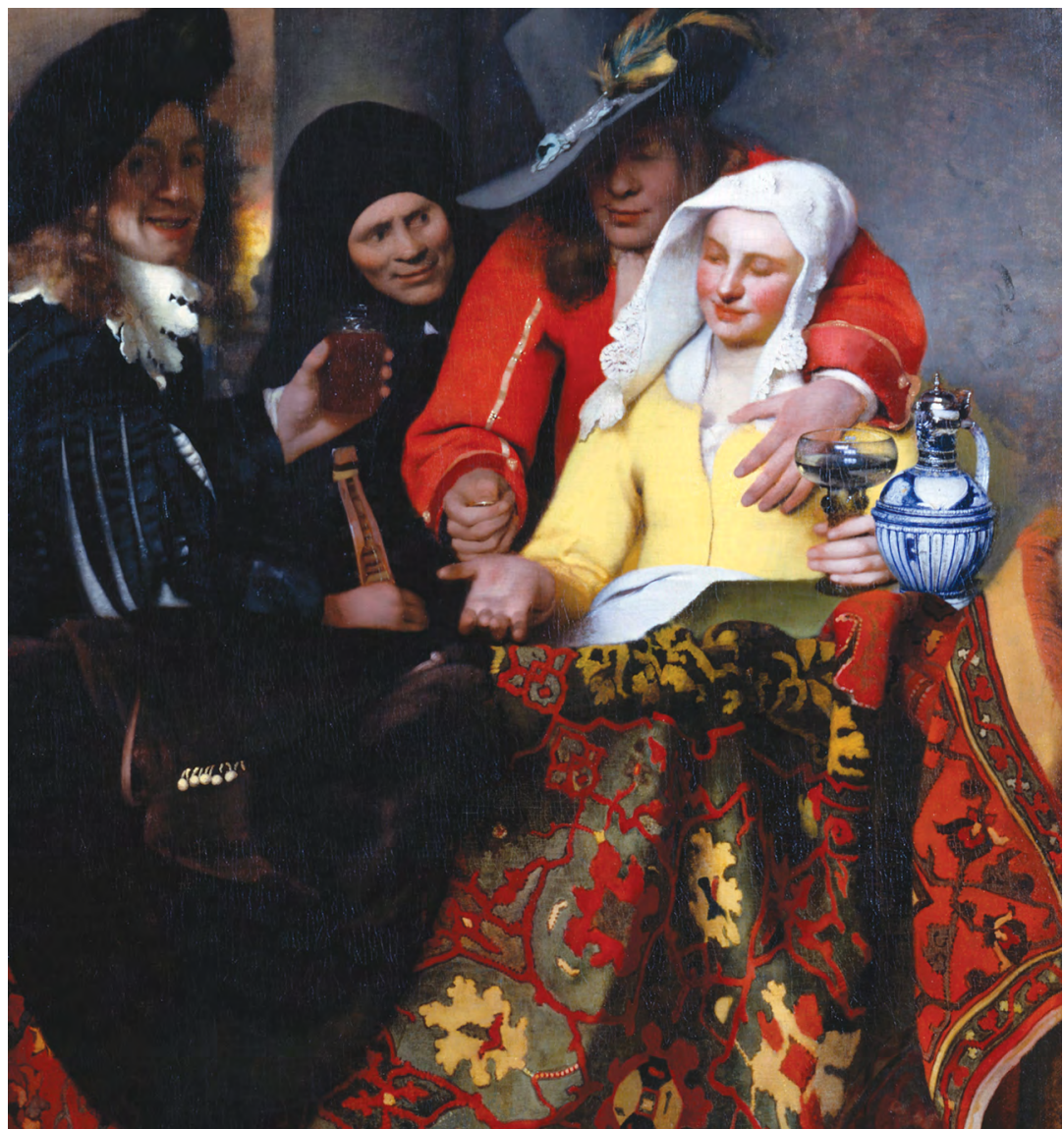

Figure 2: Johannes Vermeer, The Procuress, c. 1656.

Gemäldegalerie Alte Meister, Dresden, Germany. The happy man on the left is thought to be Vermeer. Public Domain.

There were also paintings with frank double entendres. For example, Gabriël Metsu, whose oeuvre of family life and motherly care is applauded by Dekker, also painted The Poultry Seller (Figure 3). This work shows a shabby market trader showing a rooster to a young woman. It is based on an obscene print by Gillis van Breen, which has the inscription:

'How much is that bird, poulterer?'

'He's sold.'

'To whom?'

'To the landlady, whom I bird all year long!' 52

52 Elizabeth Alice Honig, 'Desire and Domestic Economy', Art Bulletin 83, no. 2 (June 2001): 294, doi.org/10.2307/3177210. 


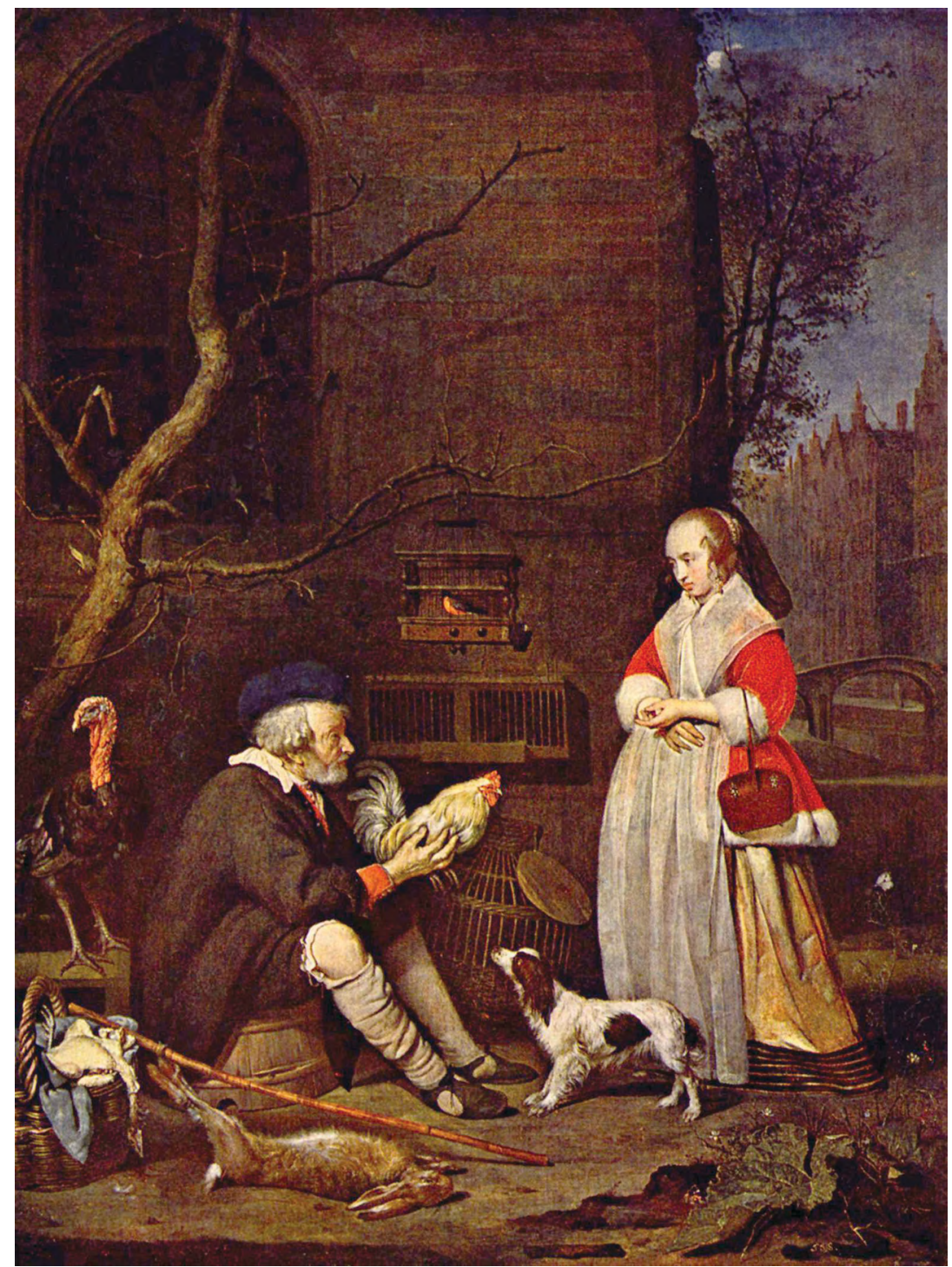

Figure 3: Gabriël Metsu, The Poultry Seller, c. 1662.

Gemäldegalerie Alte Meister, Dresden, Germany. Wikimedia Commons. 
The pun in seventeenth-century Dutch (and German) is based on the word vogel, which means 'bird' when used as a noun, while as a verb it is a slang term for sexual intercourse, still current in the Netherlands and Germany. Hence the ubiquity of poultry in 'low' paintings, for instance in Gerrit Dou's Kitchenmaid with a Boy on a Window, ${ }^{53}$ or in Gabriël Metsu's The Huntsman's Present. David R. Smith says that birds are the 'most familiar sex symbol in Dutch art'. ${ }^{54}$ For Mira Friedman, the partridge in particular was 'the image of immoderate lust and unbridled lewdness' in seventeenthcentury Holland. ${ }^{55}$ The Huntsman's Present, for example, was a partridge.

Another, more subtle, category of double entendre, or perhaps multientendre, is the much-commented-on painting by Gerard Ter Borch, The Parental Admonition (also known as The Gallant Conversation). This painting portrays 'innocent details that tell a non-innocent story'. ${ }^{56}$ Famously, the German polymath Wolfgang von Goethe had interpreted the painting's message as an innocent tale - $\mathrm{a}$ 'parental admonition' to an errant daughter. ${ }^{57}$ In the twentieth century, Ter Borch's work was seen as a brothel scene: Goethe's 'knightly gentleman' is a client, the 'daughter' a sex worker and the 'mother' a madam/procuress. In this century, some critics have restored the subjects' innocence: it is now a courting scene. ${ }^{58}$ These conflicting interpretations do not convict Goethe-anachronisticallyof unwitting naivety. They show instead that expert opinions and the state of art knowledge may show marked changes over time.

The Parental Admonition was apparently popular, since Ter Borch made dozens of copies. There are copies in the Louvre in Paris, the Rijksmuseum in Amsterdam, in the National Gallery of Art in Washington and in the Gemäldegalerie Berlin. The key to the 'brothel' interpretation is the presence or absence of money in the alleged gentleman's hand. In the Gemäldegalerie version, the coin was found after cleaning; ${ }^{59}$ in the Rijksmuseum version, the coin is not visible, but the area near the man's

53 Wayne Franits, Seventeenth-Century Genre Painting: Its Stylistic and Thematic Evolution (New Haven: Yale University Press 2004), 118.

54 David R. Smith, 'Realism and the Boundaries of Genre in Dutch Art', Art History 32, no. 1 (February 2009): 80, doi.org/10.1111/j.1467-8365.2008.00651.x.

55 Mira Friedman, 'On Diderot's Art Criticism', Assaph Studies in Art History, 2 (1996).

56 Martha C. Howell and Walter Prevenier, From Reliable Sources: An Introduction to Historical Methods (London: Cornell University Press, 2001), 206.

57 Johann Wolfgang von Goethe, Elective Affinities, trans. R. J. Hollingdale (London: Penguin Classics 2005), 246

58 Blake Gopnik, 'Exquisiteness in Plain View', Washington Times, 7 November 2004, N.01.

59 See Rijksmuseum website, www.rijksmuseum.nl/en, accessed 24 May 2019. 
hand is 'abraded' ${ }^{60}$ Some critics say they see a fingernail, not a coin. It is possible that Ter Borch 'adjusted' each copy to the customer's taste or perhaps thought that ambiguity would be a selling point. Copying was a well-known practice in this period. Some painters, not only Ter Borch, copied their own originals. ${ }^{61}$ Other contemporaries of Ter Borch also used irony and ambiguity—some were directly influenced by him. ${ }^{62}$

Among paintings that could send immoral messages were depictions of soldiers with young women where the householder's absence 'threatens to transform an otherwise respectable woman into a whore and to make a brothel of a bourgeois home'. ${ }^{63}$ A classic example is Vermeer's Soldier and Laughing Girl (Figure 4). ${ }^{64}$ Richard Helgerson associates this subgenre with the political and military history of the time-the successful end of the revolt against Spain. He suggests that householders were in some way 'entertained' by the pictorial representation of the takeover of their homes and wives' bodies by the very soldiers hired to protect them. ${ }^{65}$ Yet, it could also be argued that the 'soldier and lone woman' paintings were cautions against the peacetime perils of coping with idle mercenaries. Possibly they were also a warning to absent husbands that their wives, unlike Caesar's, were not above reproach. ${ }^{66}$ Although Dutch women enjoyed a great deal of freedom as compared to their foreign contemporaries, Dutch moralists insisted that social stability and prosperity depended on the 'untarnished virtue of their women'. ${ }^{67}$ So it is possible to see 'soldier and lone woman' paintings as economic caveats: warnings about possible losses of wealth and prestige, rather than messages about morals. Wives were regarded as valuable chattels to be guarded.

60 See 'Terborch, Gerard biography', Web Gallery of Art, www.wga.hu/frames-e.html?/html/t/ terborch/1/bp_advic.html, accessed 24 May 2019. Perhaps the 'abrasion' was censorship by the curators, the moral equivalent of a figleaf? See, for example, the 1857 'figleaf controversy' concerning the exhibition of Michelangelo's David at the South Kensington Museum (now the Victoria and Albert Museum) in London, www.vam.ac.uk/content/articles/d/davids-fig-leaf/, accessed 24 May 2019.

61 De Marchi and Miegroet, 'Art, Value and Market Practices', 453.

62 David R. Smith, 'Irony and Civility: Notes on the Convergence of Genre and Portraiture in Seventeenth-Century Dutch Painting', Art Bulletin 69, no. 3 (September 1987): 421, doi.org/ $10.2307 / 3051063$.

63 Richard Helgerson, 'Soldiers and Enigmatic Girls: The Politics of Dutch Domestic Realism, 1650-1672', Representations, no. 58 (Spring 1997): 52, doi.org/10.2307/2928823.

64 Helgerson, 'Soldiers and Enigmatic Girls', 69. See also Liedtke, A View of Delft, 177-78. Helgerson is undecided whether the subject is patriotic or if it depicts 'mercenary love'. Nanette Salomon thinks it is prurient. See Nanette Salomon, Shifting Priorities: Gender and Genre in Seventeenth Century Dutch Painting (Stanford: Stanford University Press, 2004), 113.

65 Helgerson, 'Soldiers and Enigmatic Girls', 62.

66 Plutarch, Fall of the Roman Republic, trans. Rex Warner (London: Penguin Classics 1972) 254: 'I considered that my wife ought not to be even suspected.' Julius Caesar famously divorced his wife not for actual adultery with Clodius, but for even the suggestion of it.

67 Schama, The Embarrassment of Riches, 398-404. 


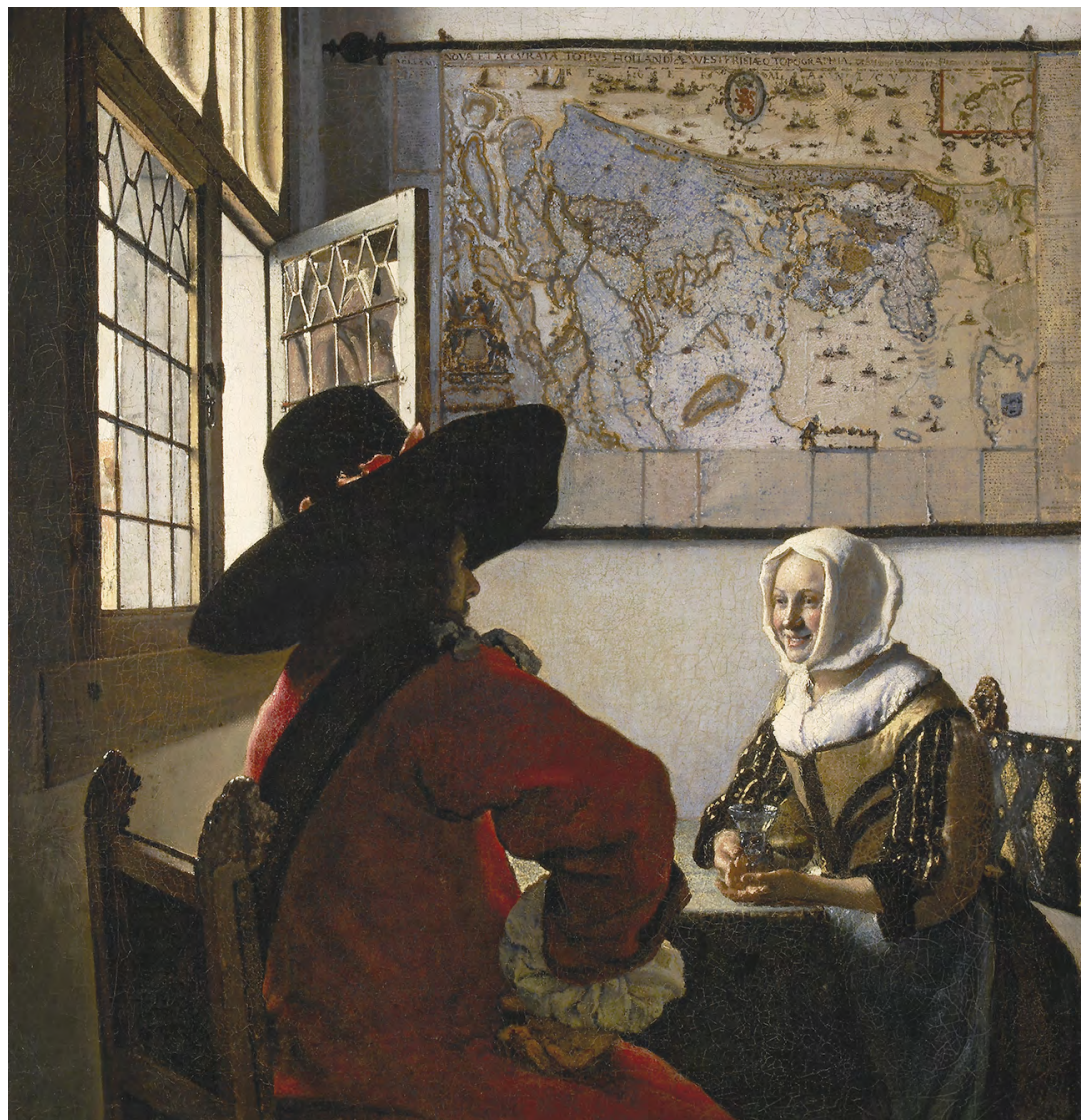

Figure 4: Johannes Vermeer, Soldier and Laughing Girl, c. 1657.

The Frick Collection, New York. Public Domain.

'Low-life' genre paintings were in demand in Amsterdam, ${ }^{68}$ covering a wide range of vulgar themes and icons. There were depictions of violence, ${ }^{69}$ urination, enemas, ${ }^{70}$ fornicating dogs, gambling, and drunken men and women groping each other. ${ }^{71}$ This demand clearly extended well beyond Amsterdam, since many of the painters of these works were based in other Dutch or Flemish cities. Pieter Bruegel, who painted Peasants Fighting Over Cards, was based in Antwerp and Brussels. Steen, based in

68 Muizelaar and Phillips Picturing Men and Women, 125.

69 Such as in Pieter Bruegel's Peasants Fighting Over Cards c. 1619. This is discussed in Walter Liedtke, 'Peasants Fighting Over Cards', Artibus et Historiae 10, no. 19 (1989): 123-31, doi.org/ $10.2307 / 1483287$.

70 See Laurinda Dixon, 'Some Penetrating Insights: The Imagery of Enemas in Art', Art Journal 52, no. 3 (Fall 1993): 28, doi.org/10.2307/777365.

71 Muizelaar and Phillips, Picturing Men and Women, 125-27. 
Leiden, and favourably mentioned by Dekker for his moral works, painted numerous taverns and drinking scenes, such as Prince's Day (Figure 5), Tavern Scene, The Dissolute Household and The Drunken Couple. He also painted enema scenes with explicit sexual imagery. ${ }^{72} \mathrm{H}$. Perry Chapman argues that Steen had a moral and didactic aim by 'playing the fool' in this series of paintings, ${ }^{73}$ but whether they actually promote the moral order is debatable. Pieter de Hooch's Young Woman Drinking with Two Soldiers, Merry Drinker and The Empty Glass fall into the 'drinkers' category. And there is usually a wineglass to hand in the brothel scenes.

Some scholars have claimed that 'low' paintings—consistent with Dekker's thesis-had a didactic function and served as cautionary tales about the dangers of vice. ${ }^{74}$ Simon Schama argues that Steen's The Dissolute Household, for instance, was an 'omnium gatherum' (hodgepodge) of such admonitions, but concedes that we have no way of knowing what the artist really intended. He suggests that perhaps the ostensible moral lesson was the 'the fig-leaf of respectability' for the sexual images. ${ }^{75}$ That sort of cynical hypocrisy was echoed much later in the tabloid press: hand-wringing over declining morals on page one followed by page three girls. ${ }^{76}$

Klaske Muizelaar and Derek Phillips argue that 'low' paintings had other functions besides moral instruction. First, they provided humour and entertainment: patricians laughing at the rough and ignorant play of poor folk, like Titania at the doings of the 'rude mechanicals' in Shakespeare's A Midsummer Night's Dream. Taken as parodies and caricatures, the paintings enhanced feelings of superiority. ${ }^{77}$ Therefore, it might be argued that the role of moral instruction was very minor, if at all present. The 'low-life' works functioned mainly as positional goods, by emphasising the neatness and decorum of the owner's home and family as compared to the rough life beyond the pale. Their role was predominantly economic and social, not moral. However, as Schama points out, thinly disguised titillation was also an important factor.

72 Dixon, 'Some Penetrating Insights', 28. Dixon discusses the sexual imagery of Jan Steen's The Doctor's Visit (1660).

73 H. Perry Chapman, 'Jan Steen's Household Revisited', Simiolus: Netherlands Quarterly for the History of Art 20, no. 2/3 (1990-91): 193-96, doi.org/10.2307/3780742.

74 Muizelaar and Phillips, Picturing Men and Women, 127.

75 Simon Schama, 'The Unruly Realm: Appetite and Restraint in Seventeenth Century Holland', Daedalus 108, no. 3 (Summer 1979), 105, 108-09, 112.

76 For example, the UK Sun, Australia's defunct Truth and Germany's Bild (formerly Bild-Zeitung) with its 'daily dose of high-resolution soft porn'. See 'Sex, Smut and Shock: Bild Zeitung Rules Germany', Spiegel Online, 25 April 2006, www.spiegel.de/international/sex-smut-and-shock-bildzeitung-rules-germany-a-412021.html, accessed 24 May 2019.

77 Muizelaar and Phillips, Picturing Men and Women, 128, 130. 


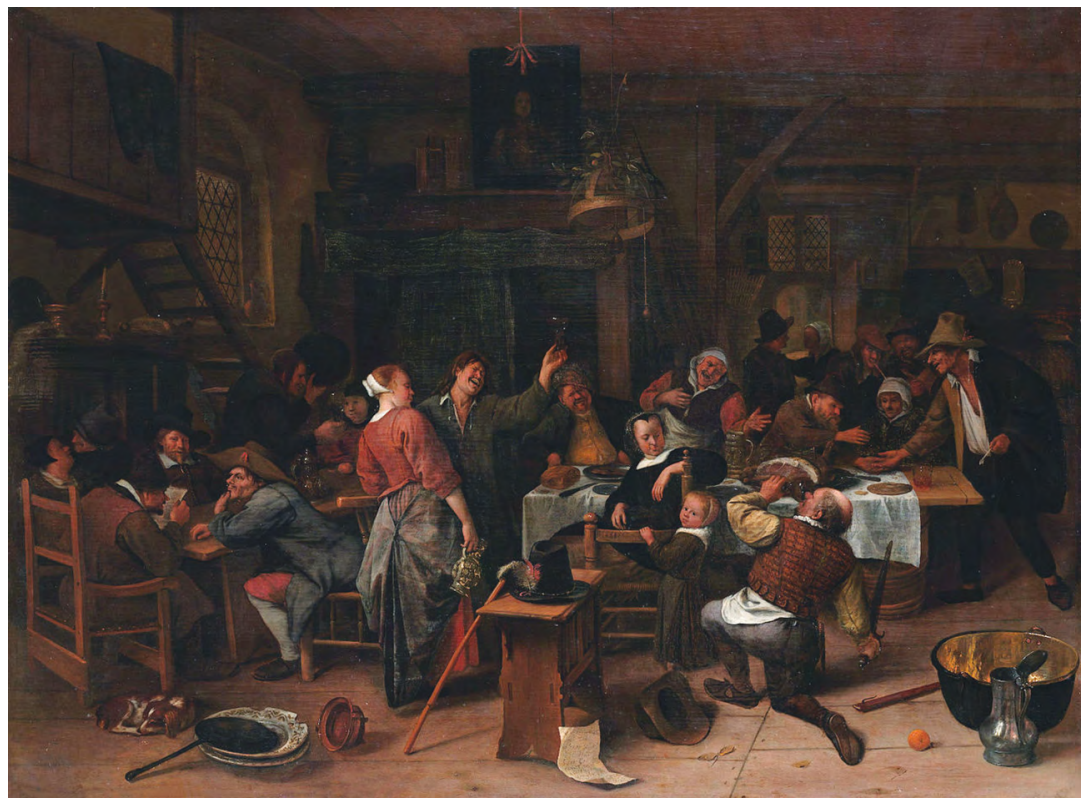

Figure 5: Jan Steen, Prinjesdag [Prince's Day], c. 1660-79.

Rijksmuseum Amsterdam, the Netherlands. Notice the small child in the foreground. Wikimedia Commons.

Where were these 'low' paintings hung? Lotte van de Pol claims that they were displayed in the more public living areas of respectable Dutch homes, although less respectable exemplars were hung in more private areas such as 'art rooms', ${ }^{78}$ where they cohabited with 'family' and 'child' pictures. There is some unpersuasive evidence for the placement of pictures in the 'painting within painting' works. This kind of 'mise en abyme' was a common practice. ${ }^{79}$ For example, in Vermeer's A Young Woman Seated at a Virginal, the painting behind her is Dirck van Baburen's Procuress. ${ }^{80}$ Eglon van der Neer's Couple in an Interior has a background painting of Venus and Cupid with copulating pigeons - the 'bird' theme again as (re)double entendre. ${ }^{81}$ Another example is Samuel van Hoogstraten's The Slippers, where Ter Borch's Parental Admonition is to be seen on a back

78 Van de Pol, 'The Whore, the Bawd, and the Artist', 1.

79 Mise en abyme, strictly speaking, 'mirrors reflecting mirrors in infinite regress', but also 'any part embedded in a work that exists in a relation of similarity with the larger work that contains it', Stone, Tables of Knowledge, 2.

80 Liedtke, $A$ View of Delft, 258-59.

81 Smith, 'Realism and the Boundaries of Genre in Dutch Art', 79-80. 
wall. ${ }^{82}$ But these deliberate juxtapositions of respectable and vulgar, moral and profane, may just have been non-too-subtle hints that the foreground subject was not 'real' and not a moral paradigm. Therefore, all this mise en abyme may be unsound or misleading evidence about where paintings were actually hung.

Similarly unpersuasive is the positioning of paintings in doll's houses. James E. Bryan says that these artworks 'functioned as virtual realities' and Susan Broomhall notes that upper-class doll's houses were a 'sumptuous extension of girls' pastimes' ${ }^{83}$ She adds that the paintings present in Dutch doll's houses were morally unexceptionable. ${ }^{84}$ Thus they cannot have been a representative sample from real life.

Art theorists of the time, both Dutch and foreign, advised against hanging 'low-life' paintings in homes, and contemporary treatises about conduct and morals warned against 'any amorous or frivolous paintings that also cunningly lead to promiscuity'. ${ }^{85}$ The influential Dutch theorist Gerard de Lairesse (1640-1711) thought that only beautiful and virtuous subjects were worthy of representation and violently criticised painters of 'low' subjects. ${ }^{86}$ In his Groot Schilderboek [Great Book of Painting], de Lairesse insisted that the artist must follow the highest moral principles-'only correct theory could produce good art'. ${ }^{87}$ Rensselaer Lee, in his survey of sixteenth- and seventeenth-century art theorists, writes that they promoted the humanistic doctrine that only 'superior forms' of human life should be represented by serious artists. ${ }^{88}$ Many well-off patrons did not follow this counsel. ${ }^{89}$ Louise Blaue, female regent (director) of an orphanage and therefore a respectable citizen, had a bordeeltje-Metsu's The Prodigal Son-hung in a public area of her home, alongside her

82 'Van Hoogstraten The Slippers: Experimenting with One's Gaze', Louvre Press Release 2008, www. museumlab.eu/press/pdf/Louvre-DNPMuseumLab_5_PressRelease_EN.pdf, accessed 24 May 2019.

83 Broomhall, 'Imagined Domesticities', 49-50. See also Loughman and Montias, Public and Private Spaces, 33.

84 Broomhall, 'Imagined Domesticities', 59-60.

85 Loughman and Montias, Public and Private Spaces, 79.

86 Muizelaar and Phillips, Picturing Men and Women, 125; Claus Kemner, 'In Search of Classical Form: Gerard de Lairesse's "Groot Schilderboek" and Seventeenth-Century Dutch Genre Painting', Simiolus: Netherlands Quarterly for the History of Art 26, no. 1/2 (1998): 90. For de Lairesse's influence, see Horton A. Johnson, 'Gerard de Lairesse: Genius among the Treponemes', Journal of the Royal Society of Medicine 97, no. 6 (June 2004): 301-03. A Treponeme is a sufferer from Treponema Pallidum (syphilis).

87 Johnson, 'Gerard de Lairesse', 301-03.

88 Rensselaer Lee, 'Ut Pictura Poesis: The Humanistic Theory of Painting', Art Bulletin 22, no. 4 (December 1940): 201, doi.org/10.2307/3046716. Ut Pictura Poesis means: 'as is painting, so is poetry'.

89 Muizelaar and Phillips, Picturing Men and Women, 125-27. 
most valuable paintings. ${ }^{90}$ Blaue's example is inconsistent with Elizabeth Honig's claim that wealthy women were often the purchasers of paintings and would not have permitted sexually provocative works to be in their homes. Honig, a feminist art historian, writes that artworks had to appeal to women's tastes. But such claims show the difficulties with projecting modern sensitivities onto the tastes and morals of the past. Muizelaar and Phillips criticise the logic of Honig's claim. They argue that if women were the prime decision-makers, as she asserts, this meant that the erotic images, so often found in public spaces in Dutch homes, must have appealed to them. ${ }^{91}$ They go on to say that we do not know how decisions were made about the display of paintings - by husbands, by wives or by negotiation. ${ }^{92}$

It would be ahistorical to say that the seventeenth-century Dutch saw the odd symbiosis and cohabitation of 'low' and 'high' paintings in the same way that we might today. Despite the Calvinist ascendancy, they appear to have been quite relaxed about the depiction of sexual subjects. From 1650 on, the Dutch Republic was known as the 'sex shop' of Europe. Large numbers of pornographic works were printed-plays, prints and books. ${ }^{93}$ Contemporary sex manuals were extraordinarily frank and their availability in cheap editions was evidence of the wide availability of information about reproduction. ${ }^{94}$ Van de Pol writes that prostitution and brothels were suppressed to some extent by the authorities, hence the existence of the Spinhuis in Amsterdam. ${ }^{95}$ But she also mentions that Amsterdam largely tolerated and secretly regulated the very public sex trade. ${ }^{96}$ Friedman claims that it was difficult to separate inns from brothels, hence the Dutch proverb 'inn in front, brothel behind'. ${ }^{97}$

90 Muizelaar and Phillips, Picturing Men and Women, 135, 141, 143.

91 See also 'Montias Database of 17th Century Dutch Art Inventories', The Frick Collection, research.frick.org/montias, accessed 24 May 2019. Bordeeltje (brothel paintings) in 'public' areas are frequently listed.

92 See discussion of Honig's argument in Muizelaar and Phillips, Picturing Men and Women, 142-43.

93 Inger Leemans, 'Arousing Discontent: Dutch Pornographic Plays, 1670-1800', Journal for Early

Modern Cultural Studies 12, no. 2, (Spring 2012): 117, doi.org/10.1353/jem.2012.0007.

94 Schama, The Embarrassment of Riches, 424.

95 An institution for reforming 'wayward' women. See Schama, The Embarrassment of Riches, 477-78.

96 Van de Pol, 'The Whore, the Bawd, and the Artist'.

97 Friedman, 'On Diderot's Art Criticism', 123. 
In artworks, we see a sanitised version of sex work. Sex workers were depicted in fashionable clothes and elegant surroundings, filtering out the reality of poverty, frequent violence and premature ageing due to drink and venereal disease. ${ }^{98}$ This euphemistic approach suggests that glamourised portrayals of sex for sale were not offensive to art consumers. Similarly, attitudes to drink were not automatically negative. ${ }^{99}$ Therefore, it may well be ahistorical to say that art owners and their visitors were scandalised by 'low' works, however much these works were disapproved of by moral guardians outside the home. ${ }^{100}$

What can we conclude about Dekker's thesis? I accept that there were numerous instructional and morally elevating works in the realist genre and that art consumers and their social circle did derive-or professed to derive-moral lessons from them. But, as I have argued, moral qualities played a minor role in the marketing of art. Paintings were valued on economic and social grounds-as positional goods and markers of prestige. If organised moral campaigns, 'communications policies' or 'education strategies' by artists played any significant role in determining demand, surely that would have been mentioned in the economic history studies discussed above. Individual artists may arguably have had moral strategies, but this sort of altruism must have been a luxury for painters without independent means. They had to paint to live and 'low' works sold. ${ }^{101}$

Further study of the factors determining the relative survival rates of 'low' and 'high' works would give more insight into Dekker's claims about preferences for moral artworks. Analysis of contemporary letters and diaries that discuss paintings would also give more evidence on tastes and attitudes. We do not see moral messages in the diary of John Evelyn, the famous English diarist and art critic (1620-1706). He was a correspondent of the eminent fellow diarist Samuel Pepys (1633-1703). Evelyn records at length the many Dutch artworks encountered in his trip to the Netherlands on official business. But he makes little mention of

98 Van de Pol, 'The Whore, the Bawd, and the Artist'. Also see Schama, Embarrassment of Riches, 475. It is true that some of the madams/procuresses were depicted as old crones (not Vermeer's).

99 Salomon, Shifting Priorities, 32. Salomon writes that moderate drinking was socially acceptable (despite Calvinist strictures), but excess drinking was disapproved of.

100 See discussion of this point in Muizelaar and Phillips, Picturing Men and Women, 149-50.

101 Muizelaar and Phillips Picturing Men and Women, 128. 
ANU Historical Journal II, Number 2

their moral aspects in his diary. ${ }^{102}$ Dekker's claim that the predominant function of 'low' paintings was to give a moral stimulus is doubtful. There were other, less high-minded, factors at work, as shown above. 'Low' works must have been in demand at the top end of the market, given that they have also survived to the present day and not necessarily because of their civilising influence.

102 John Evelyn and Guy De la Bedoyere, eds, The Diary of John Evelyn (Woodbridge: Boydell, 2004). For a discussion of Evelyn's description of the Dutch art market, see Lisa Jardine, Going Dutch: How England Plundered Holland's Glory (London: Harper Perennial, 2009), 121-22. 
This text is taken from ANU Historical Journal II: Number 2, published 2020 by ANU Press, The Australian National University, Canberra, Australia.

doi.org/10.22459/ANUHJII.2020.02 